\title{
ADRIAN VICKERS Bali rebuilds its tourist industry
}

Most of us are familiar with the shape of Bali's tourist industry. 'Cultural tourism' is still the dominant policy, and outlook, amongst Balinese, even though in recent years this policy has become increasingly divorced from the resort tourism of the island. But in the decade immediately after Indonesian independence was fully attained, the tourist industry had to be rebuilt and a variety of strategies for attracting foreigners attempted. The rebuilding of the industry was accomplished in a surprisingly modern manner, in ways that have been forgotten in subsequent accounts of the industry.

In the period 1946-1949, an aptly named Dutch economic official, G. Koopman, had sought to re-establish tourism in Bali as part of the Dutch attempt to restore their empire to its pre-War state; between 1950 and 1965 Indonesians began to focus on re-establishing tourism for themselves, by producing tour guides and setting up specific organizations to take advantage of increasing numbers of foreigners.

The rebuilding of tourism displays many of the post-colonial dilemmas of Indonesia. Local needs and local nationalism had to be integrated into the new state and nation, but this could only be done by making use of the materials and ideas left over from the colonial era. In the predominantly socialist ideology of the new Indonesia, new kinds of local capitalism and entrepreneurial activity came to the fore. The people who had led the physical struggle against Dutch rule now had to re-deploy Dutch images and structures, especially to attract foreign, predominantly Western, audiences to Bali. Given the anti-Western national rhetoric of the time and the post-colonial context of Bali, this was an inherently ambivalent process.

The tourist industry of the island was first established by the colonial power, based on representations of Bali as an 'island Eden'. While tourism was not, at least at this stage, the major component of Bali's economy, it was seen by local and national authorities as a priority area for a new emerging

ADRIAN VICKERS is Professor of Southeast Asian Studies at the University of Sydney. His books include $A$ history of modern Indonesia (Cambridge: Cambridge University Press, 2005), Journeys of desire: A study of the Balinese Malat text (Leiden: KITLV, 2005), and Bali: A paradise created (Ringwood, Vic.: Penguin, 1989). He can be contacted at<adrian.vickers@sydney.edu.au>. The author would like to thank the late I Gusti Ngurah Bagus, I Nyoman Darma Putra, Henk Schulte Nordholt, Kadek Jango Pramartha, Michel Picard, Carol Warren and I Nyoman Wijaya for assistance, particularly with some of the primary sources for this article; as well as Nengah Bendesa, Nyoman S. Pendit, the late Nyoman Ratep and Made Mertih for generously passing on their experiences. Original research was funded by an Australian Research Council grant. 
nation, especially as a way to display pride in culture. The rebuilding of tourism in Bali after the chaos and destruction of the Second World War and the Indonesian Revolution required building on, and reinterpreting, experiences from that colonial era. Souvenirs, accommodation, entertainment, and guiding of tourists all had to be taken over by Balinese and other Indonesians, who had to work out how and what to present to outside audiences. How were commodified relations with foreigners established so soon after Indonesia achieved its independence?

\section{Bali in the 1950s}

Bali in the 1950s mirrors the problems current in the rest of Indonesia. Jef Last's account of Bali (1955:7) begins with Soekarno attempting to quell the internal divisions that were the legacy of the Revolution. Such divisions persisted in the forms of banditry and resistance to the state, including resistance by participants in the physical Revolution, who were unhappy with its outcomes. Geoffrey Robinson's excellent study (1995) is still the main contribution to our understanding of this kind of politics, in particular how much Bali's political fate was tied to Jakarta. Integration into Indonesia meant both the recreation of an institutional framework, and the embrace of a new disposition towards the modern.

Violence went hand-in-hand with a positive embrace of the modern, and an attempt to enact modernity at the local level. Nyoman Wijaya (2000) has shown how Balinese versions of modernity permeated into everyday life. Nyoman Darma Putra $(1997,2003)$ has pointed out two aspects of this modernity in his work on women. First, Balinese women were emerging as leaders and achieving equality, but on the other hand, there was great moral panic about the role of women and emancipation, part of a general discourse about Indonesia going through a moral crisis, or krisis akhlak. Nyoman Wijaya's recent $\mathrm{PhD}$ thesis (2010) takes the discussion further by showing how class and social conflict in the period were played out in local struggles over religion and society.

Tourism was also one of the focal points of social change. As a newly conceptualized industry, it held great hopes, not only for Bali, but for other parts of Indonesia as well. A scene in Ismael's film Tamu Agung shows the village head expressing his plans for tourist development to help his mountain village progress in Java, and other parts of Indonesia also aspired to development through tourism, as government publications of the time show. Only Bali had the existing reputation to take full advantage of this aspiration, however.

There is not a great deal of information on the public record concerning Bali's tourism in the 1950s. Michel Picard's fine work (1996) on tourism and 
the discourses of culture deals with the colonial period and the major preoccupations of New Order Bali, but the period in between is rather sketchy. Geoffrey Robinson (1995) says little on how politics converted into a new tourist industry. Likewise Andreas Tarnutzer's study (1993) of Denpasar's development has little to say on tourism in this period.

\section{Tourism and art shops}

Tourism is partly about selling things, although not all the participants may see it that way. As an industry it brought Balinese into the world of post-War capitalism, but the transition was not a smooth one from Dutch to Indonesian control. Rather, there was a long transition which carried over from the period of the Revolution, and in which Dutch personnel, as well as ideas, played a part.

One aspect of selling 'Bali' has been the growth of 'art shops', which developed in the colonial period, and the re-establishment of which was a fundamental part of rebuilding tourism after the Japanese occupation. The Dutch, having successfully killed off, imprisoned or driven into the hills the major freedom fighters of Bali, established Bali as part of their puppet state, the State of Eastern Indonesia, or NIT (Negara Indonesia Timur). The NIT was headed by a Balinese president, Cokorda Raka Sukawati of Ubud, and had a Balinese prime minister, Anak Agung Gede Agung. The NIT established the organization HONET (Hotel Negara dan Tourisme) in 1947 (Pendit 1997). During the NIT period a Dutch architect, G. Koopman, established himself in the coastal village of Sanur, setting up the Art Gallery Sindhu near the site of a former tourist shop. Koopman was soon followed by a Dutch citizen of mixed descent originally born in Java, Jimmy (James Clarence) Pandy. ${ }^{1}$

Koopman and Pandy, with quality control from the Dutch artist Rudolf Bonnet and initiatives from the famous Balinese sculptor and entrepreneur Ida Bagus Tilem, were the most prominent actors in marketing Balinese culture as a series of art objects. The first was opposed to Indonesian independence, while Pandy and Bonnet had ambivalent relations to the nationalist movement, although Bonnet in particular was later to get to know Soekarno well.

Koopman arrived in 1946 as the Dutch government's Head of the Ministry for Economic Affairs in Bali; his shop was something of a diversion for him, but only in part. Professionally he was interested in re-establishing tourism and all its traits. Koopman probably encouraged Pandy to come back to Bali in 1949, for the latter had been a Thomas Cook agent before the War and had the experience and ability to market the island. The two men were clearly

$1 \quad$ Bakker 1985:46-7; Kam 1993:75-6. My thanks to Made Mertih and Nyoman Ratep for the information that Pandy was already working on Bali in the 1930s, personal communication, 23-9-1997. 
friends, and were dining together in $1950^{2}$ when assassins, suspected of working for the Republican cause, killed Koopman and a guest.

Koopman and Pandy established shops modelled on that of the pre-War Sanur aquarium and souvenir shop run by the German Neuhaus brothers, Hans and Rolf (Bakker 1985:28-36). Bonnet, as an artist concerned with promoting Bali's art, in his pre-War work with the Museum Bali and the Pita Maha artists association of Ubud, had established the position that what should be sold was quality 'art', not commercial junk. Imprisoned by the Japanese in Makassar, he was eagerly sought by Balinese and Dutch alike as an adviser on Balinese culture during the NIT period. That influence persisted after independence, when Soekarno patronized Bonnet, and purchased paintings from him (De Roever-Bonnet 1993:43-62).

Art was an important part of the image of Indonesia, as both the Republicans and their enemies knew, and this art made a major contribution to the way that tourism was to define Bali. In 1948-1949 an exhibition of Indonesian art was sent by the Dutch to the United States. ${ }^{3}$ By late 1948, after purging their communists, the Republicans were gaining support from the United States in the diplomatic side of their struggle for independence. This Dutch-sponsored exhibition was organized with the participation of the puppet Federal States, with NIT's Balinese Prime Minister A.A. Gede Agung on the organizing committee. At the behest of Agung's government, Bonnet had assembled the collection for the East Indonesian Federal State (Sukawati 1979:40).

Artists such as I Ketut Regig and I Ketut Rudin made contact, direct and indirect, with the foreigners living in Sanur. For them this was a matter of survival, and the wider politics of image and independence did not come into consideration. I Regig, formerly known as I Lendjoe, arrived in Sanur from Peliatan in 1942 and began to take over the Sanur preference for depicting animals. Frogs became the main subject of his work, and when the new shops opened, he made contact with their owners.

After the Japanese period, things here were really tough. I worked in the rice fields, and then I did a bit of painting for Tuan Pandy... and for the shop which had been set up at Tanjung Bungkak [on the way from Sanur to Denpasar ${ }^{4}$ ] ... I used to work for [polih gae] twenty-five [rupiah?].

21949 in some oral sources, but see Coast 1954:113-4.

3 The catalogue is entitled INDOnesian Art: A loan exhibition from the Royal Indies Institute, Amsterdam, The Netherlands. New York: Asia Institute, 31 Oct.-31 Dec. 1948; Chicago: The Art Institute of Chicago, 16 Feb.-31 Mar. 1949; Baltimore: Baltimore Museum of Art, 24 Apr.-29 May 1949. The Balinese paintings had previously been exhibited in Amsterdam, Tentoonstelling van Oost-Indonesische Kunst Schilderijen, Beeldhouwwerk, Weefsels en Zilverwerk ter Gelegenheid van het Gouden Regeringsjubileum van H.M. Koningin Wilhelmina. Amsterdam: Indische Instituut, 25 Aug.-1 Oct. 1948.

4 This shop was also mentioned to me by I Ktut Rudin, who lived near it. Another Dutch entrepreneur had opened this second shop. 
Could Sanur artists sell to tourists in the Hotels? In the Bali Beach?

There was no Bali Beach then that the government owned, there was the Sindhu Hotel first.

Did artists sell their work there?

No, everything was sold through Tuan Pandy's. ${ }^{5}$

Koopman encouraged Rudin to move away from the wayang style of showing shadow-puppet-like figures in traditional narratives. ${ }^{6}$ Rudin had a background as an organizer of dances, especially the legong dance of young girls which was founded as a court dance and a variety of exorcistic rites. In the 1930s this dance became one of the most popular dance forms by which Bali was known. Nyoman Darma Putra in his interview with I Rudin elicited the story:

So Koopman didn't like wayang [shadow puppet-style]?

No, he didn't like it... He'd just return any wayang paintings I gave him. But I really liked them... if he took any it was just because he felt sorry for me, knowing how much I liked them...

So he gave me some other examples, examples of drawings of legong. These were little sketches.

Whose sketches? I Regug [another Badung artist]?

No, Robias [Miguel Covarrubias], an American. 'Can you do this? Try copying this? If you can, I'll take what you do; that's the only thing that will sell. Take it home...' So I did what Koopman was happy with. 'But you don't have to finish them off - once you've done the basic lines bring them here. If you haven't got the basis, I'll fix it for you.' - That's what he said to me. So I did it and went on foot to Sindhu [some five or six kilometres from Rudin's house at Renon]. I finished it off, and once it was done I took it there. 'I'll take a basic sketch' - I went there, going along with what he said.

How many sketches do you mean?

Eh?

How many sketches did you take there?

Just the one, at first. Once I'd established the basis I could finish it off, so then I went home and finished it. Once it was done I took it again to him, and he was happy, now he was happy.

Did tourists come there?

Yes, they used to buy a lot of my paintings there. ${ }^{7}$

5 Author's interview with Regig, 12-7-1996.

6 Author's interview with Rudin and Nyoman Darma Putra, 11-12-1996.

7 Interview with I Ketut Rudin by I Nyoman Darma Putra, 29-8-1996. 
Covarrubias had produced the summative book on Bali that contained all the colonial images of the island, although his own position was ambiguous, since he was a cosmopolitan Mexican progressive. The drawings of legong dancers on plain backgrounds came to be much imitated, to the point where they became standard souvenirs, surviving to the present day. Legong dancers became the principal image for use in all aspects of tourism, superseding other images such as the demonic witch, Rangda, which had been important for the magical image of Bali in the 1930s. More importantly, this small example sums up the problem of Balinese painting, that its representational dynamic was subordinated to the needs of tourist industry image-making.

Rudin sold a few works with Pandy, but after Koopman's death another dealer emerged, this time a Balinese sculptor with a keen sense of the importance of his colleagues' works, Ida Bagus Tilem of Mas, a village between Batuan and Ubud. Tilem was quickly able to see the marketability of the new types of works promoted by Koopman. Besides Ida Bagus Tilem and Jimmy Pandy, a number of others began to market art. On the beach of Sanur the Belgian artist Le Mayeur's Balinese wife, the famous dancer Ni Pollok, used her husband's contacts to sell paintings. Rudin and many of the Sanur painters would sell their works through this tough but extremely fair woman.

Art shops maintained the artistic image of the island and provided the greatest distribution of income to Balinese. The fame of Ida Bagus Tilem and Jimmy Pandy belies the fact that they were probably some of the very few males involved in the trade. A group of Denpasar women had sold carvings and other items to tourists in the Bali Hotel in the 1930s. Nyoman Rapeg, then a young girl, recalled how they were instructed by the manager to dress in traditional costume, not to speak to tourists until they were summoned, and to keep their hands modestly down, rather than wave their arms around. She would also walk to Sanur to sell to the aquarium-owning Neuhaus brothers, Hans and Rolf (known in Balinese as Tuan Bé, 'Mr. Fish'). She and a number of her colleagues were not allowed to go to the Bali Hotel when the Japanese came, so they formed a cooperative, PIDI (Persatuan Isteri Dagang Indonesia), and opened a shop in Jalan Gajah Mada, just around the corner from the hotel. After the War this shop was called the Ratih, and was on the south side of the street, opposite the Chinese-owned Denpasar Hotel, which became the Mega art shop in the 1970s. Nearby was the Wisnu Theatre and one of the two petrol pumps and bus stations in Denpasar.

Nyoman Rapeg set up her own shop in 1951, the Sutji art shop, and at around the same time one of her PIDI colleagues, Jero Nuratni, set up Toko Pelangi in Grenceng, behind the Bali Hotel. At that time the Oka and Klungkung art shops were also established, the Oka by a family from Glogor, 
in what was then southern Denpasar, the Klungkung by Made Catri, from that regency. ${ }^{8}$

Gradually as tourism came back, the money came. In the 1950s as part of the re-establishment of the industry the Balinese institution of the 'art shop' was established. Some of those who set up these art shops were former painters from the 1930s who had saved their capital or converted it into rice fields, and who could call on networks of artists and carvers they met at the time.

In Klungkung a group of women who owned antique shops beside the market in the 1930s continued to accumulate stock from the 1940s onwards, based on their earlier wealth, although many of the items they acquired remained unsold until the late 1960s and early 1970s. These shops were listed in a 1956 list of 45 art shops made as part of a meeting to plan tourist policy in Bali. The Klungkung shops are listed under the names of Men Kundri (Gana), Made Tinggen (of Kamasan painters' village), Made Krebek (possibly from the house of Jeroan Lebah) and Ketut Djiwa. ${ }^{9}$

Madé Tinggen was the most active of these, frequently travelling to Denpasar, where she became a very good friend of Nyoman Rapeg, sleeping at her house when she needed to stay overnight. Via Tinggen, Rapeg obtained Kamasan paintings, cloth and silver, although she also travelled to Kamasan village and knew the artists and gold- and silversmiths. Her Sutji shop mainly dealt in carvings, setting up a production series based on set models which their contracted (langganan) carvers from Meduwi and Pemogan villages knew well. A.A. Rai Dana of Peliatan was their main source of Ubud art prior to 1965, thereafter Nyoman Munut. Beli Kerta in Celuk was their main supplier of jewellery, before his family set up the Dewi Sri shop, one of the first in that village. Sutji established a network of wholesalers (grosir) which extended to Jakarta, and they regard the 1960s and early 1970s as high points in the carving trade, after which the competition from specialized shops, along with the decline in wood sources, meant that selling from the shop alone was no longer viable. They still sell through their networks outside Bali, particularly statues of the Virgin Mary to Christians. ${ }^{10}$

8 Interviews with Nyoman Rapeg and Made Mertih (her daughter-in-law), 24-9-1997. Rapeg's husband, Ktut Rena, was a klian or head of the Banjar of Belaluan. With money from the shop they purchased two Impalas in the 1960s so that their son, husband of Mertih, could become a driver and guide at the Bali Beach. Mertih was already related to the family, and her father, Made Tantra, was a charismatic political leader of the PNI, and organizer of the Gong Belaluan who learned English from working with an Australian widow of a missionary in Sayan, Mrs T. Pattinson, also known unflatteringly as Nyonya Mokoh ('Mrs Fat'). He also knew Ketut Tantri, John Coast and Ni Pollock, and the family were related to Nyoman Nyongnyong. My thanks to Siobhan Campbell for an article on Mrs Pattinson in The Courier Mail, 28-10-1938.

9 ASITA Bali archives, Denpasar, Daftar Toko Keradjinan dan Kesenian di Bali. Donald Friend in Sanur, and then the anthropologist Anthony Forge, became two of their keenest buyers.

10 Interviews Nyoman Rapeg and Made Mertih, 24-9-1997. Made Mertih studied English at the University of Indonesia with Murtini Pendit, wife of Nyoman S. 
In Ubud, Made Pacung (of the Nomad shop) established the first art shop in the 1950s, although only I Gosong is listed in the 1956 list. ${ }^{11}$ Maintaining the pre-War Batuan artist and freedom fighter, Ngendon's, role in his village as a retailer of art, relatives of his ran the Dewata gallery, strategically placed on the road between Denpasar and Ubud. In the 1956 official list of art shops produced for policy planning meetings, two others are listed in Batuan, owned by the artists Ida Bagus Tibah and Ida Bagus Sentul(an), both from the priestly house (geria) with which Ngendon had worked; in Mas the sculptor Ktut Rodja, as well as Ida Bg Rupa (cousin of Tilem) and four others; in Peliatan, Wayan Tegug; in Kamenuh, Ketut Tulak; in Bedulu, Nyoman Toko; four shops in Celuk; Pandy and Ida Bagus Mas of Sanur, and the rest in Jalan Gajah Mada and Jalan Ngurah Rai (now Veteran) in Denpasar, including the still existing Pelangi and Kresna. In Denpasar itself in pre-War times there had been a number of Chinese-Balinese-owned shops in the main street (such as Mega) which continued to sell carvings and paintings from all over the island, and these survived for many decades. The family of the Mega art shop were also related to one of the main local photographers, Auw Kok Heng (1913-1976) of Hwa Heng Studio. It was not until 1957 that Made Sura of Batubulan opened the first shop selling carved tuff stone statues to tourists, followed by Made Geg in 1960 (Geria 1975). Women, invisible in the standard histories, played a central role in this aspect of the industry. Their role showed a strong social basis for possible developments of the tourist industry.

\section{Foreigners promoting Bali}

Once the new Republic of Indonesia controlled the whole archipelago, sympathetic foreigners also promoted Indonesia to the world through Bali, but through nostalgic reference to the Bali of the 1930s. The pre-War tourist image kept re-appearing to capture the possibilities of development in Bali, even when it was not the Dutch who were involved. The encounter with foreigners became more complex in this era.

One of the partisans of Indonesian independence was a remarkable English adventurer, John Coast, survivor of the Burma Railway, English agent in Thai post-War politics, and eventually someone who was able to lend diplomatic assistance to the new president Soekarno, during the struggle (Coast 1954). For this he was well regarded by the new government, and allowed to live in Bali, where he established a cultural mission which would tour Britain and the United States. This mission, involving many from Ubud and Peliatan who had been part of the 1931 Balinese presence at the Paris Colonial Exhibition, was now an assertion of independent Indonesia's culture.

11 Information Graham MacRae, 17-4-1997. 
Coast was one of a number of post-War writers to continue the traditions of travel writing which were intrinsic to the development of the tourist image of Bali. He self-consciously sought to recreate the pre-War lifestyle depicted in Colin McPhee's book, A house in Bali (1947), to the point of finding McPhee's cook and enlisting the handsome dancer I Sampih (1926-1954), McPhee's 'discovery', to be central to his tour. Such star billing, combined with a propensity to philandering, was what most Balinese consider as the motive for Sampih's murder on returning to Bali. Rudin's paintings were part of the tour, and Coast took his many guests to meet artists and see cultural shows.

Jacques Chegaray (1955:10) writes of the early 1950s, 'access to Bali is not easily obtained. Not everybody who wants to can land here, and visas other than for transit are rarely granted.' Coast, like Last, describes the physical danger for foreigners of being on the island. Intriguingly, though, Coast's book is peppered with accounts of foreigners passing through, Europeans and Americans, and tourism appears as a constant backdrop to his life there. Balinese involved in tourism remember the period up to 1954 as very quiet, with boats beginning to stop at Padang Bai in 1954. It was not until a few years later that significant numbers of tourists came. ${ }^{12}$

One of the interests which shines through Coast's book, dominating the photographs and the image of the book and the tour, is the legong. Already praised by the pre-War writers, to Coast the little girls become emblematic of the island.

On the Balinese side there was interest in foreigners. I Rudin was one of a number of artists who had become interested in foreigners in the pre-War period, despite the usual idea that Balinese saw all foreigners as demons or raksasa to be afraid of. Rudin was one who looked up to Coast, particularly after the Englishman helped him get treatment for beriberi.

When I was sick with beriberi he helped. I asked to get the help of a dukun (traditional healer) at the time, but it was not given, because that was the age of freedom, people couldn't believe in dukun any more. He asked me, do you agree to a doctor? I said 'I agree, but let's try a dukun's medicine first'.

The next day it was pouring with rain, I was brought to the doctor first thing. Because it was early in the morning he had not yet woken, I think Coast knew him, because he could wake him up. I was examined by the doctor, given medicine, and had to sleep elsewhere... I was brought to the hospital at Wongaya, and he [Coast] used to come pretty often, to visit me, along with Koopman. One or the other used to come. When they'd gone home the nurses in the hospital would ask me, 'why have you got white men as friends?' At that time people were scared of the Dutch. ${ }^{13}$

12 Interview with Nyoman Ratep, 24-9-1997.

13 Interview with Darma Putra, 27-8-96. When she was little in the 1950s, Bulan Tresna Djelantik, daughter of A.A.M. Djelantik and his Dutch wife, Astri, remembers being pelted with stones, accompanied by shouts of 'londo' (Dutch girl) because of her Eurasian appearance (personal communication, 18-1-2010). 
Ambivalence towards foreigners was quite strong. Rudin was clear in his strong anti-colonial feelings. The Dutch, in his view, used coercion and 'put us down with words', which he put in the same category as the physical violence of the Japanese. But for Rudin the foreigners he had met on Bali in the 1930s were 'different', good people. Nyoman S. Pendit, one of the Tentara Pelajar or Student Army of the Revolution, saw fighting against colonialism as something divorced from personal relations with the Dutch: 'we are freedom fighters, but we never considered that we must kill Dutch men'. ${ }^{14} \mathrm{He}$ also recalled that sexual relations with foreigners were not unusual, and that Balinese did not disapprove 'as long as it didn't bother anyone else'. ${ }^{15}$ In what we have of the record of building a tourist industry in the 1950s, there is only indirect allusion to this industry having a 'colonial' or 'imperial' tint or taint. Apparently the Indonesian Communist Party, PKI (Partai Komunis Indonesia), opposed tourism because tourists came from the 'enemy' imperialist countries. ${ }^{16}$ Like the 'Kuta cowboys' of the 1970s, for whom sexual relations with foreign women held a different promise of modernity, the artists engaged in selling to tourists represent Balinese voices in favour of desirable exoticized foreigners.

For many post-colonial theorists, colonialism is a trauma, a rupture, epistemic violence, assumed to be uniform in its effects on subject populations. Dutch colonialism was experienced by the people to whom I have spoken in South Bali for somewhere between 34 and 36 years, 42 at the most. Accepting the Indonesian nationalist rhetoric of '350 years' of foreign rule, most writers regard the duration of colonialism as indicative of its impact. While not doubting that impact at an institutional level, the post-colonial testimonies indicate a more complicated set of interactions. One of the ways to examine this is to ask why Indonesians should have perpetuated the tourist imagery of Bali created in the colonial period.

\section{Freedom fighters and hotels}

If Koopman and Pandy gave the NIT's tourist industry a Dutch identity, their successors and competitors in the industry were largely those on the other side of the Revolution. Ida Bagus Kompyang, one of the first Balinese tourist hotel owners, had been a comrade of two of the leading guerrillas during the Revolution, Wijakusuma and Pak Poleng. Indonesian tourism's chief Balinese strategist Nyoman S. Pendit had also fought in the Revolution, and wrote

14 Author's interview, 17-9-1997.

15 Author's interview, 17-9-1997. This was in response to my mentioning the sexual relations between Ktut Tantri ('Miss Meng' - 'Cat Lady' to Balinese) and the dancer, priest and Hotel Bali employer Nyoman Nyongnyong, discussed in Pendit 1992.

16 Nengah Bendesa, press release, 6-8-1997. 
the definitive account of the struggle on Bali in the 1950s. These nationalists sought to create a clearer picture of what people should see in Bali, and how, providing both accommodation and a mental map of the island to consolidate the activities of the souvenir industry. As with the souvenir industry, the itineraries were built on pre-War foundations.

When Dutch expatriate Jef Last, socialist teacher and supporter of the Indonesian Revolution, wrote of tourism in the early 1950s, he described the archetypal tourist as American, staying the typical five or six days of the Dutch-owned Koninklijke Paketvaart Maatschappij (KPM, Royal Packet Company) tours, in the Bali Hotel in Denpasar, dealing with Chinese taxi totes (Last 1955:64). Artist Le Mayeur's house in Sanur was the only 'small paradise' most of these tourists saw there, with his wife Ni Pollok dancing the legong. Ubud was still part of the 'unknown' Bali. The fact that Anak Agung (Tjokorde) Gede Sukawati, ruler of Ubud, had a guest book and played host to foreigners, again showed continuity with the past, but was a sign of things to come. Last's observations of Bali were deep enough for him to know that tourism and westernization were not the same thing, and he doubted that Balinese culture would disappear with tourism - citing the example of Switzerland. Not all tourists, he said, were regarded as capitalists and imperialists; John Coast was a good example of a foreigner who had created goodwill (Last 1955:91).

Other sites on the 1950s tourist map which Last (1955:62) mentions are Goa Gajah and Sangsit, places to stop and take photos. Last (1955:83) himself maps out the possibilities for tourist developments with astounding foresight: trips to the idyllic mountain lakes and Besakih, water sports at Benoa and Serangan, and sailing to the pretty little spot of Nusa Dua which his friend Pan Katjong had pointed out to him. Knowing that Bali had little industrial potential, he argued that tourism was its main resource (Last 1955:90).

Many in Bali agreed, and Last and Coast should be seen as reasonably influential, given that Last had an impact on many of his students in North Bali (including the wife of Nyoman S. Pendit), and formed good cooperative relationships with A.A. Pandji Tisna, one-time king of North Bali. Coast as diplomat and entrepreneur had all the right political connections.

\section{Itineraries}

Veteran tourism manager I Nengah Bendesa remembers when he became a guide for the Nitour company in 1962 that guidebooks were still a problem, and not all of the books mentioned were readily available in Bali. His qualifications were that he had learnt English at Gadjah Mada University in Yogyakarta. Having studied to be a teacher, he found the salary of Rp. 600 per 
month inadequate to live off, but the first time he tried his hand his English was so rough and his knowledge of any of the sights so slight that he was ridiculed by a German tourist. Disheartened, he enlisted to serve in the Irian Jaya campaign, was rejected and had another try at being a guide. This time he was successful, and a group of ladies from Palo Alto gave him a tip equivalent to his month's wages as a teacher. He used Miguel Covarrubias's Island of Bali and some country guidebooks published by Japan Air Lines. Famous guide Nyoman Oka and others who had a lot of contact with foreigners were often given books which helped both their work and their English. ${ }^{17}$

David Stuart-Fox's bibliography of writings about Bali (1992) lists 62 works published between 1940 and 1960 under 'Travel', and this section does not include Coast's book or others on dance that would have attracted overseas interest, including work by Henri Cartier-Bresson and Antonin Artaud (1954). Amongst these writers was the Indonesian author E. Kattopo, who published a book on Bali in 1950 (1958). The national Ministry of Information published numerous books in this period.

Other Indonesians were also active in promoting Bali. In 1954 the indigenous Chinese, Soe Lie Piet, published his Introduction to Bali (Pengantar ke Bali) ${ }^{18}$ Although not as famous as his sons, Soe Hok Gie and Arief Budiman, Soe Lie Piet is a significant cultural figure, for he had already published a guidebook and travel account in the 1930s, as well as two novels of Bali. His particular 'take' on Bali is its connections and affinities with Chinese culture, but otherwise his 1954 book, reworking his 1935 Malay text, is a guide to Balinese culture with an extensive list of places to visit: Banjarankan, Bangli, Batubulan, Batuangsel, Bedulu, Besakih, Bila, Bubunan, Bongkasa, Lake Bratan, Darmasaba, Jimbaran, Denpasar, Gelgel, Kebutambahan, Kusamba, Lukluk, Panulisan, Pejeng, Sangeh, Sangsit, Sawan, Sempidi, Singaraja, Sukawati, Taman Bali, Wongaya Gede, Tampaksiring, and Candi Kuning. Kuta is also mentioned in his possible itineraries set out in the latter part of the book. Not all of these fit our present tourist map of the island, but it is there in parts.

Soe Lie Piet tells us more about the number of government-run pesanggrahan or guest houses, a hangover from the colonial period, and the existence of Chinese hotels. He gives a longer list of the dances than the legong, baris, barong and kecak which emerge from accounts such as that of Coast. The pesanggrahan he mentions are at Baturiti, Bedugul, Gitgit, Kintamani, Klungkung, Munduk, Negara, Petang, Pulukan, Selat, Singaraja and Tirta Empul, at Rp. 7.50-10 per night. ${ }^{19}$

17 I Nengah Bendesa, personal communication, 6-8-1997.

18 My thanks to John Maxwell for lending me a copy and providing background information.

19 In his 1930s account there was more detail: the Satria Hotel, owned by a Dutchman, existed then, the three Chinese hotels were the Soen An Kie, Hotel Baroe and Oriental Hotel, and for 7.50 guilders you could rent accommodation in Tampak Gangsul on a longer term basis, 1935:4-6. Note the pre- and post-War prices seem to have been the same. 
Tampak Gangsul, referred to in Soe's 1930s account as somewhere you could get cheap longer-term accommodation, maintained that fame until the 1970s, as I well remember from my first trip to Bali, when the Adi Yasa Hotel there was one of the famous hippy stopovers.

The leading Brahmin (brahmana) family from Tampak Gangsul, included Ida Bagus Kompyang, who was actually born in Buleleng, where he became a young freedom fighter. Like others from this generation I have met, he went into business in the post-revolution period, starting with export-import, and using the profits from that to establish a hotel. In 1956 he set up Segara Beach Hotel, with 15 rooms and its own electricity. His wife, A.A. Mirah Astuti, played a major role in managing the hotel. Locals gave him the name of 'Grandfather West' for his knowledgeable dealings with foreigners, and people such as Soekarno and Prijono sought him out. ${ }^{20}$ This move anticipated the nationalization of Dutch firms when martial law was declared in the leadin to Guided Democracy.

Sanur was an important choice, since the Sindhu art shop was already there, and the Dutch-owned KPM owned a 10-room hotel nearby. I.B. Kompyang's hotel was next to Jimmy Pandy's, and just north of the KPM's Sanur (later Sindhu) Beach Hotel. At around the same time a series of hotels was set up to the north of this area, especially Alit's Bungalows (owned by a member of Denpasar's royal family, A.A. Alit), and Diwangkara, owned by another Denpasar figure, Ida Bagus Oka Diwangkara, who had also been a freedom fighter and local politician. His wife seems to have actually done the running of the hotel, and they also owned a hotel in Denpasar. Further south the Tanjung Sari Hotel (10 rooms) was established by Wija Wawaruntu, a Menadonese (who may have been related to Pandy). These initiatives seem to indicate impatience with the KPM's domination of tourism, and in 1956 the Dutch company's hotels were taken over by the Indonesian Natour (Darma Putra 1994:4).

These Balinese initiatives had been anticipated by other Indonesians. K'tut Tantri, a foreigner who had given support to the revolution, had owned a hotel in Kuta in the pre-War period. It was destroyed by the Japanese, but the Indonesian artist Agus Jaya contracted the land from her landlord, I Nyoman Nyongnyong, in 1950, setting up the Sanggar Wisma Samudra Beach Kuta, as a kind of artists' guest house. By 1956 after negotiation with the new Balitour agency the Wisma was turned into a 'tourist centre'. Again the documents reveal that while Agus Jaya was the owner, it was his wife who was the business manager (Asita Bali archives). In all these cases we should not underestimate the role of Indonesian, especially Balinese, women as the major entrepreneurs of tourism, although they usually only get a mention as 'Mrs...' in the records and retrospective accounts.

20 Interview by Pujastana for the Bali Oral History Project, 1996. See further the special stories on the history of tourism, Bali Post, 15-6-1996. 
The actual Indonesianization of KPM's Bali Hotel was carried out in 1956 when the National Tourist Agency, Natour, took over all the KPM hotels. In 1961 the Javanese new head of Natour, Sunaria Prawira Diraja, took over the Kuta Beach lease from Agus Jaya for Rp. 750,000, although in 1967 the lease reverted to Nyongnyong, so Natour purchased the Kuta land for Rp. 4,500,000. The new Sindhu Beach (at one stage called the Narmada) Hotel and Kuta Hotel were not built until 1972. ${ }^{21}$

Agus Jaya's example shows that domestic tourism was important. There were many smaller establishments of the kind discussed by Soe Lie Piet which catered more to domestic travellers, called pelantjong, than foreign touristen (a term taken from Dutch). In 1956 there were 40 hotels, losmen and pesanggrahan on the island, according to government documents (Darma Putra 1994; Asita archives). ${ }^{22}$ These included in Denpasar: the Losmen Gambuh of Ida Bg Oka Diwangkara, Losmen Elim in Jalan Kartini Denpasar, L. Mam On/Lay A. San (Jalan Gajah Mada), L. Tjien Hwa Tulangampian, Losmen Badung in Wangaya; in Ubud: Hotel Mutiara (owned by Cok. Gd Ngurah, brother of Cokordas Raka and Agung Sukawati), the Puri Ubud Guesthouse (Cok. Agung Sukawati); Pemeregan: Losmen Brahma run by Ida Aju Mirah Arsini; Tabanan: Losmen Hartaman (owned by the lord of Krambitan) and Losmen Kota Tabanan (owned by the king of Tabanan; Geertz 1963:110). There were some 12 hotels and losmen in Singaraja, with slightly more Balinese than Chinese ownership. One of the Singaraja hotels was owned by I Nyoman Kajeng, who had been a member of the radical nationalist movement Surya Kanta in the 1930s, a librarian at the Gedong Kirtya, which preserved traditional literature, an official under the Dutch, a freedom fighter, and a post-Revolution politician. Another at Lovina was owned by A.A. Pandji Tisna, the famous royal novelist who was a friend of Last's. A number of the losmen were owned by Muslims, presumably as halal stays for other Muslims.

\section{Entertainment}

There were a few restaurants with the hotels, but they seem to have been minor businesses, often run out of the Chinese-owned losmen and hotels. Taxi companies were largely Chinese-run, The Tiong Sien ('Mr T') being the main contractor for Balitour.

21 'Ternyata semuanya berawal dari Bali Hotel', Bali Post, 15-6-1996. Tim Lindsey, K'tut Tanti's biographer, tells me that the ownership of the land had in fact been in dispute at the outbreak of the War, and this involved a legal case with her former partners who owned a hotel on adjoining land, Robert and Louise Koke. The documents from that court case were destroyed in the Battle of Surabaya.

22 Lampiran 693/14, DPRD Peralihan Daerah Bali, 8 June 1957; and separate Bali Tour listing of hotels: Daftar Hotel, Losmen dan Pesanggarahan di Bali. 
Ni Pollok was also one of the first to provide entertainment for foreign guests. She pioneered the holding of cultural evenings or lunches with Indonesian food for guests, and was still doing this in the early 1970s, when I attended one such evening with joged (flirtatious dances). Ida Bagus Kompyang claimed to have held the first 'Bali night' of the joged dance and babi guling (roast suckling pig), an initiative he took to Jakarta. ${ }^{23}$ The Bona Kecak (or Monkey Dance) was already in operation as a 'business' at the time, but not, it seems the two Batubulan Barong dance-drama performances, the first of which, Barong Denjalan, began in 1963, while the related Joged Tegaltamu started in 1964 (Geria 1975:82). Commercial legong performances were already established at Abiankapas by the early 1960s. 'The Dancing Girls of Bali' could be seen in Kesiman by 1960 (Pendit 1997:15). The dominance of legong is surprising in the light of the popularity of the Barong as an attraction since the 1970s.

Thanks to tours such as that organized by John Coast, the musicians of Peliatan, led by A.A. Mandra, remained the most famous of Bali, eventually eclipsing the Belaluan group which had originally held sway since the 1920s because of their connections with the Bali Hotel. The full effect of that eclipse was not felt until the 1960s, since the Belaluan group, led by Made Tantra was still involved in 'Arts Missions' (Misi Kesnian) to countries such as China and Russia during the Soekarno period. ${ }^{24}$ The eclipse of the various musical groups outside of Peliatan matched the move towards the centrality of Ubud as the home of the arts from the 1960s.

Soekarno's patronage was important in determining what should be presented to foreigners. As a young girl, Bulan Tresna Djelantik, whose father was then head of the main hospital in Bali, would often be summoned by Soekarno to dance the legong for guests in the Presidential Palace at Tampaksiring. These included Robert Kennedy in the early 1960s, and Ho Chi Minh in 1959. The latter performance was held with Soekarno's own daughter, Megawati. ${ }^{25}$ Another dancer at the time was Bali Governor A.A. Bagus Sutedja's daughter. Involvement of the elite in dance was a very new development. Prior to this time, female dancers, especially adults, were regarded as prostitutes. In Denpasar and a number of other areas they had separate graveyards, since their mobility around the island, their participation in travelling troupes, implied ambiguous power. ${ }^{26}$ Soekarno, Sutedja and the others who encouraged their daughters to dance made the practice respectable, and thus part of the cultural mainstream of activities for middle-class Balinese.

23 Interview with Pujastana.

24 Information from Made Mertih and family.

25 Bulan Tresna, personal communication, 18-1-2010.

26 G.M. Sutjaja, personal communication. 
The travel bureaus and the role of government

Tourism was and was not a profitable business. Seeing the opportunities created by superseding the KPM, nationalist freedom fighter Nyoman Oka led a number of Balinese in establishing Balitour and coordinating with a variety of shops, hotels and taxi drivers. This last phase of the 1950s involved an organizational consolidation of the activities that had been taking place on various entrepreneurial fronts since the late 1940s.

Oka was an energetic and charismatic man who later became regional head (bupati) of Tabanan. Balitour, like many of the enterprises of the time, was established along cooperative lines, and many of those involved seem to have been socialist in inclination (Geertz 1963). However in 1956, when Balitour was established, the total number of tourists visiting Indonesia was only 9,064, rising to 26,206 in $1966 .{ }^{27}$ The figures are vague and unreliable, but regional government figures show that 'Tourism Taxes', padjak pelantjong, were an important source of revenue for the island at the time it was being established as a separate province:

$\begin{array}{ll}\text { 1953: } & \text { Rp. } 26,750 \\ \text { 1954: } & \text { Rp. } 34,700 \\ \text { 1956: } & \text { Rp. } 116,030 \\ \text { 1957: } & \text { Rp. } 134,500^{28}\end{array}$

In 1958 the average tourist was spending US\$180, in 1967-1968 \$200 (Data ekonomi regional 1969, II:13).

Balitour, first called Gabungan Tourisme Bali, included I Gusti Putu Merta, one of the island's leading politicians and head of the regional parliament, on its board. Major shareholders were NV Wisnu (the Chinese-owned picture theatre), NV GIEB (the largest and most important of the exportimport cooperatives), NV Modjopahit (owned by Gede Puger, a major leftwing politician close to Governor Sutedja), and the Regional Government or Dewan Pemerintah Daerah Bali, as well as the handicraft cooperative, Yayasan Keradjinan Bali. Besides Nyoman Oka, others involved were Wayan Dangin (also head of Bali's Agricultural Service) and Putu Rudolf (head of Bali's Trade Inspection Department). Oka seems to have done all the work, since he was paid Rp. 2000 per month, a figure set by the board, more than five times what the bookkeeper, mechanic and typist were paid, and ten times what Ida Bagus Karang, the only guide in 1956, was paid as a retainer,

27 'Indonesia bandjir wisata? Angka-angka jang bitjara', Suluh Marhaen, 1-9-1968.

28 Angka2 perbandingan anggaran2 belandja Daerah Bali tahun2 1954 dan 1955...1953 dan 1954...1956 dan 1957. Cornell University Microfilm. The conversion rate comes from the Asita Bali archives, Nitour annual report for 1959. In 1959, US\$1=Rp. 34. 
although he was actually paid a separate rate every time he went out with tourists. ${ }^{29}$ Nyoman Oka also worked personally as a guide, his most famous duty being for Queen Elizabeth II. ${ }^{30}$

The regional government, DPRD (Dewan Perwakilan Rakyat Daerah), was involved in detailed planning discussions with Balitour. These were in response to Balitour's requests for credit. A long report recognizes tourism as 'one of the most important paths to raise the prosperity (mempertinggi kemakmuran) of the People (Rakjat) on this island. According to this source the satisfaction (kepuasan) of tourists (para pelantjong) was the island's greatest advertisement. Tourism should work 'to attract the attention (minat) and desire (keinginan) of the tourists'. But this was done in the recognition that 'the material situation of the people is certainly inadequate, and service for tourists and guests will be run accordingly, so that the tourists and guests will suffer accordingly. Thus tourism will not run smoothly (macet).' Here there may be veiled recognition of potential hostility, which is defused in terms to peladenan, which in later discussions becomes the English term 'service'. Laden has less overtones of 'serving' in a menial fashion than other terms, since it can mean simply 'helping' and also 'paying attention to' someone. ${ }^{31}$

A related planning document sees tourism as needing two things, 'infrastructure' (kelengkapan) such as good roads, and 'beautiful panoramas' (panorama2 jang indah2). This means that there had to be 'Objects of excursion or interesting objects to visit; Performances and other attractions; Shops where tourists can buy souvenirs with a price and service which satisfy' (Object2 tamasja atau object2 perkundjungan jg menarik; Tontonan dan attracties lainnja; Toko2 dimana para touris dapat membeli souvenirs dengan harga dan peladenan (service) jang memuaskan...). The Indonesian side of the tourism business was to cater for a modern population who were becoming 'weekend-minded' and would thus want to holiday in Bali. ${ }^{32}$ Thus domestic tourism was seen as being an equal part of the industry.

Tourism is here defined in a mixed language, combining Indonesian, English and Dutch terms. The word pelantjongan has a relaxed connotation, of sightseeing or an excursion. Bertamasya, a word of Indian origin that was officially used, was only slightly more formal in its meaning. Indonesians and foreigners can equally take part in this, particularly as Indonesians become more modern and better off. The experience is defined visually, but transactions such as buying souvenirs are not purely commercial, but part of a mutually satisfying experience. The language of this is not the language of 'culture' and 'cultural interaction' of later tourism.

ASITA Bali archives, Laporan Singkat BALITOUR 1956.

I Nengah Bendesa, personal communication, 6-8-1997.

ASITA Bali archives, Lampiran 693/14, DPRD Peralihan Daerah Bali, 8-6-1957, my translation.

ASITA Bali archives, Rentjana: memadjukan tourisme di Bali. 
A January 1957 meeting of the Tourist Council of Bali and the local government (especially Sutedja and G.G. Oka Puger) considered a Musjawarat Tourisme that had taken place in Tugu in 1956. The main Balitour people present were Nyoman Oka, I Gusti Ngr. (Anak Agung Alit) Konta (a member of a minor Denpasar royal family) and $\mathrm{Nj}$. Ida Bagus Aryawidjaja. The importance of published guidebooks was discussed here as an outcome of the previous meeting. ${ }^{33}$

Another item of discussion in the 1957 meeting was the things that disturbed tourists (gangguan). These included enthusiastic sellers at Gunung Kawi and Goa Gajah archaeological sites, and the direct charging of entry prices. It was noted that in 1955 at least one of the KPM ships refused to go to Jakarta anymore because of beggars. Non-Muslim Bali had a competitive edge. There was also the gangguan of cattle, and the worry that tourists would witness people bathing. Tourists were supposed to be witnesses to a landscape and ancient culture, as well as witnesses to modernity. In discussions of restoring the water palace at Ujung, the governor asked that the important temple Pura Luhur at Tanah Lot be included as an 'objek'.

The period 1956-1959 was one of sustained regional revolts, part of the reaction to which was nationalization of former Dutch enterprises, the establishment of martial law and then Guided Democracy. All this proved bad for business. The years 1957-1959 saw persistent declines in Western tourist numbers and consistent losses for Bali Tour, as these figures for tourists who came via Nitour show: ${ }^{34}$ 1957: 2,284; 1958: 1,950; 1959: 1,630. Balitour consistently made losses, but was kept viable by the continued visits of cruise ships to the island (Darma Putra 1994:5). The economic difficulties of the time came to a head in 1960 when Balitour was forced to incorporate into the private national company Nitour, which had originally been established in 1952 when the Sultan Hamengku Buwono IX of Yogyakarta (later Vice-President during the establishment of the New Order) bought out a Dutch company. This was the outcome of attempts by the national government to obtain a major stake in Balitour, during which I Nyoman Oka remarked that 'I'd rather sell peanuts than merge' (Darma Putra 1994:6) By law Nitour was given an initial monopoly, meaning that there was no choice but to merge. Ida Bagus Kompyang ran the Bali office of Nitour. Two years later other companies, not Balinese-owned, were established: Natrabu and Bali Lestari Indah.

The industry's problem is the same as the political problem identified by Geoffrey Robinson (1995): Bali was dependent on Jakarta, and the industry worked from there. The 1960s saw the industry removed from Bali effective-

33 ASITA Bali archives, Tjatatan singkat mengenai Rapat Dewan Tourisme Daerah Bali jang diadakan di Balai Masjarakat Denpasar pada tgl 3 Djanuari 1957.

34 ASITA Bali archives, Annual reports of Balitour. For 1958 there are two figures for the number of tourists, 1,950, and 1,916. 
ly, with Jakarta coming to shape the nature of the developments. Fortunately the journalist Nyoman S. Pendit maintained a Balinese voice in these developments, in 1958 becoming Director for Foreign Affairs in the Indonesian Council for Tourism, and then liaising with various international organizations, including the Pacific Area Travel Association (PATA). He directed the first Travel Guide Course, run by the government in Jakarta in 1962, and wrote some of the first books in Indonesian on the subject of tourism. In 1961, finding that the word tourisme, inherited from the Dutch, had taken on a number of negative connotations, and feeling that the words pelantjong and tamasya were not effective for the industry, he consulted with the leading nationalist ideology Moh. Yamin and Professor Prijono (Minister for Culture, who had a doctorate in the study of Middle Javanese Literature from Leiden University). They came up with the term pariwisata, a Sanskritized term meaning 'fulfilled journey', which Pendit then set about publicizing in his work as a journalist. ${ }^{35}$ In his book on tourism, produced from his research in the United States, Pendit (1965) was the first to talk about 'cultural tourism' as one of the forms of the industry, thus setting the basis for what was to become the main policy direction in the post-Soekarno period.

\section{Old to New Orders}

In the 1950s, central government planning of tourism was established, and the shape of the industry identified in terms of the 'objects' and the goal of 'service'. Soekarno's enthusiasm for Bali confirmed this, and hijacked Balinese control over the image-making process. In 1963 tourist development was supposed to come to a climax with PATA holding an Indonesian conference (organized by Nyoman S. Pendit), from which the major office holders were to go to Bali as the showcase of Indonesia's tourism. But Bali's Gunung Agung erupted, leading to thousands of deaths, and so these plans were disturbed.

Soekarno was still pleased to bring guests to Bali. He had his own palace in the mountains at Tampaksiring (built in 1957; Wijaya 2010:466, note 81), although not all his guests stayed there. Soekarno was particularly a patron of Ubud, to where many important guests were escorted, and this link helped the village to establish its present fame as the artistic centre of the island.

The government-owned Natour had plans for a modern national hotel network which began with the Hotel Indonesia, moving on to the Ambarrukmo in Yogyakarta, and then to be crowned by the Hotel Bali Beach, which eventually was run as an Intercontinental. There seems to have been a tension between the regional attempts to control this process and the national attempts, which 
are also caught up with politics. The government departments dealing with tourism were dominated by leftist parties, and so suffered in the aftermath of 1965. Many involved with the Bali Beach were arrested (and presumably executed) during the Coup. ${ }^{36}$ Ida Bagus Kompyang emerged to take over the building of the hotel, which he saw to completion in 1966.

It did not take long for those now taking control to set tourism plans in motion. A planning document from December 1965 makes it clear that

The opening of the region of Bali for tourism (kepariwisataan) has been an enterprise already 'established' since the pre-War period. To increase this enterprise, we await the coming success in expanding the ways of drawing (daja tarik) visits (pengundjungan) (especially from overseas). (Bali 1965.)

The language here is deliberately technical, in line with later New Order rhetoric. As a long-term process tourism is presented as having its own momentum - as not needing to provide attractive and satisfying experiences. Pelantjongan had been replaced as the word for 'tourism' with the more neutral and technical pariwisata. This was an indicator of the professionalization of tourism, as signalled by the use of foreign advisers. The Hotel Bali Beach had a succession of foreign general managers with their American and European ideas of management and the industry. ${ }^{37}$ By this stage tourism training courses were established on the island. ${ }^{38}$

The 1950s was an era of other possibilities, both in terms of Balinese mentalities and economic control. The modern-minded Balinese of the era did well out of tourism, but did not see it in the same terms as the present industry does. Those whose experiences had been forged by colonialism and the Revolution exhibited a remarkable flexibility and adaptability to new economic and political circumstances. The 1950s tourists were strange and fickle, to be entertained and served, not harassed. As Indonesians became modern they would blend into the mode of leisure that was tourism. The legong dance would serve as an emblem for the island, and the 'art' of Bali would provide souvenirs of a relationship established, not necessarily as profitable in itself.

For Bali tourism promised autonomy and a new way of seeing themselves in relation to the rest of the world, albeit one based on colonial image-making and structures. The 1950s represented a partially fulfilled promise of independence, in which some Balinese with great initiative were able to forge a new kind of social position and the island itself gained relative autonomy. However national politics, particularly Bali's special status for Soekarno, inhibited Bali's move towards autonomy. The island proved too rich, too full

36 Suara Indonesia, 15-11-1965.

37 'Services diperlukan', Suluh Marhaen, 2-9-1968.

38 Advertisement, Suluh Marhaen, 2-9-1968, 4-9-1968. 
of promise to be left to Balinese. The 1950s remained then as an alternative path for Bali, one in which bottom-up development could have occurred. By the 1970s, the imposition of national and international plans ensured that the Balinese would necessarily be the controllers of their own destiny, the centralized state was in full flight. The genuinely post-colonial moment of the mid-1950s never realized its full potential. Post-War tourism had promised something more modest than the later tourism, a Bali of panoramas and performances, a lesson that nothing is inevitable, especially the present contours of tourist development.

\section{References}

Unpublished sources

ASITA Bali [Tourist Organization] archives

Private archives

Published sources

Bakker, Wim

1985 Bali verbeeld. Delft: Volkenkundig Museum Nusantara.

Bali

1965 Bali. [Denpasar]: Direktorat Djendral Tjipta Karja, Departemen Pekerdjaan Umum.

Cartier-Bresson, Henri and Antonin Artaud

1954 Les danses à Bali. Paris: Delpire. [Collection 'Huit' 2.]

Chegaray, Jacques

1955 Bliss in Bali. Translated by Princess Anne-Marie Callimachi. London: Barker. [Originally published as Bonheur à Bali: L'̂̂le des tabous. Paris:

Coast, John Amiot-Dumont, 1953].

1954 Dancing out of Bali. London: Faber and Faber.

Darma Putra, I Nyoman

$1994 \quad$ Itinereri Asita Bali. Denpasar: DPD Asita Bali.

1997 'Pariwisata budaya: Antara polusi dan solusi'. Paper, Lokakarya Internasional Pelestarian Warisan Budaya Bali, Denpasar, 29 July.

2003 Wanita Bali tempo doeloe; Perspektif masa kini. Denpasar: Bali Jani.

Data ekonomi regional

1969 Data ekonomi regional Bali: Pertanian, peternaka, perikanan, demography, fasilitas sosial, pariwisata, perdagangan, industri. Direktorat Tata Kota dan Daerah, Direktorat Djendral Tjipta Karja, Departemen Pekerdjaan Umum

Elliott, Jan dan Tenaga Listrik. Two vols. Workers and unions in Jakarta, 1945-1965. PhD thesis, University of New South Wales, Sydney. 
Freitag, Thomas U.

n.y. Bali... in the eye of the beholder: 3 Balinese photographers, Auw Kok Heng, Karyadinata Sujana, Ida Bagus Putra Adnyana. Sanur: Griya Santrian Gallery.

Geertz, Clifford

1963 Peddlers and princes: Social change and economic modernization in two Indonesian towns. Chicago/London: University of Chicago Press.

Geria, I Wayan

1975 'Konflik sebagai suatu masalah dalam perkembangan pariwisata budaya', in: I Gusti Ngurah Bagus (ed.), Bali dalam sentuhan pariwisata. Cetakan Kam, Garrett ke-2, pp. 77-84. Denpasar: Universitas Udayana. [First edition 1974.]

1993 Perceptions of paradise: Images of Bali in the arts. Ubud: Yayasan Dharma Seni Museum Neka.

Kattopo, E.

1958 Bali, pulau kahjangan. Tjetakan 2. Bandung/Jakarta: Ganaco. [Kenallah Tanah Airmu 2.] [First edition 1955.]

Last, Jef

1955 Bali in de kentering. Amsterdam: De Bezige Bij.

Liem, Maya H.T.

2003 The turning wheel of time: Roda jaman berputar: Modernity and writing idenMcPhee, Colin tity in Bali 1900-1970. PhD thesis, University of Leiden.

$1947 \quad$ A house in Bali. London: Gollancz.

Pendit, Nyoman S.

1965 Pengantar ilmu pariwisata, Djakarta: Djembatan.

1992 'Jadi pramuwisata lewat pengalaman', Cakrawala Pariwisata 3-15 (JuniJuli 1992):13-5.

1996 Hindu Dharma abad XXI: Kesejahteraan global bagi umat manusia. Denpasar: Yayasan Dharma Naradha.

1997 'Pariwisata bermula dari tamasya', Suara Karya 10-9-97:13, 15.

Picard, Michel

1996 Bali: Cultural tourism and touristic culture. Singapore: Archipelago Press. Robinson, Geoffrey

1995 The dark side of paradise: Political violence in Bali. Ithaca, NY/London: Cornell University Press. [Asia East by South.]

Soe Lie Piet

[1935a] Pengoendjoekan poelo Bali atawa gids Bali. Malang: The Tjwan Khee.

1935b Melantjong ke Bali. Soerabaia: Tan's Drukkerij.

1954 Pengantar ke Bali. Djakarta: Magic Carpet Book.

Stuart-Fox, David J.

1992 Bibliography of Bali: Publications from 1920 to 1990. Leiden: KITLV Press. [Bibliographical Series 19.]

Sukawati, Tjokorda Gde Agung

1979 Reminiscences of a Balinese Prince. As dictated to Rosemary Hilbery. [Honolulu]: n.n. [University of Hawaii, Southeast Asian Studies, Southeast Asia Paper 14.] 
Tarnutzer, Andreas

1993 Kota adat Denpasar (Bali): Stadtentwicklung, staatliches Handeln und endogene Institutionen. Zürich: Geographisches Institut, Universität ZürichIrchel. [Anthogeographie 12.]

Wijaya, I Nyoman

2000 '1950s lifestyles in Denpasar through the eyes of short story writers', in: Adrian Vickers and I Nyoman Darma Putra with Michele Ford (eds), To change Bali: Essays in honour of I Gusti Ngurah Bagus, pp. 113-34. Denpasar: Bali Post.

2010 Mencintai diri sendiri: Gerakan Ajeg Bali dalam sejarah kebudayaan Bali 19102007. Yogyakarta: Program Pascasarjana Fakultas Ilmu Budaya, Universitas Gadjah Mada. [PhD thesis, Universitas Gadjah Mada, Yogyakarta.] 